distribution of cerebrospinal fluid differs from that seen in most cases of hydrocephalus.

A possible explanation is that due to impairment of circulation of cerebrospinal fluid, in case 1 due to the Arnold-Chiari malformation and in case 2 due to adhesions after intraventricular haemorrhage, most of the expansion of cerebrospinal fluid spaces causing raised intracranial pressure occurs over the surface of the brain. This is quite difficult to detect by ultrasound but causes the same net effect to the brain as ventricular dilatation does in the more usual cases.

We think these two patients are unusual, but their cases illustrate the importance of not relying on the size of the ventricles to indicate raised intracranial pressure and the need for insertion or revision of a shunt system. Measurement of ventricular pressure is mandatory in any patient in whom there is raised intracranial pressure and whose ventricles are normal on ultrasound.

\section{References \\ ${ }^{1}$ Skolnick ML, Rosenbaum AE, Matzuli T, Guthkelch AN, Heinz ER. Detection of dilated cerebral ventricles in infants: a correlative study between ultrasound and CT. Radiology 1979;131:447-51. \\ 2 Johnson NL, Mack LA, Rumack CN, Frost M, Rashbaum C. B- mode echoencephalography in the normal and high risk infant. AJR 1979;153:375-81.}

Correspondence to Dr D W Pilling, Alder Hey Children's Hospital, Liverpool L12 2AP.

Received 14 February 1985

\title{
Hepatitis B virus replication in acute glomerulonephritis with chronic active hepatitis
}

\author{
P CADROBBI, F BORTOLOTTI, G ZACCHELLO, R RINALDI, M ARMIGLIATO, \\ AND G REALDI \\ Divisione di Malattie Infettive dell'Ospedale Civile, Clinica Medica $2 a$ e Clinica Pediatrica \\ dell'Università Padova, Italy.
}

SUMMARY A 3 year old boy who had chronic active hepatitis type $B$ with features of ongoing liver damage and active virus replication, developed acute membranous glomerulonephritis two years after the clinical onset of liver disease, when both hepatitis $\mathrm{B}$ e antigen and antibody were detectable in serum. After withdrawal of short term steroid treatment and resolution of hepatitis B virus replication, both glomerulonephritis and chronic hepatitis went into remission. Some months later hepatitis B surface antigen was no longer found in serum.

In recent years reports from different countries have emphasised the high prevalence of hepatitis B virus markers in the serum of children with membranous glomerulonephritis. ${ }^{12}$ On the other hand hepatitis B virus antigens together with immunoglobulins and complement components have been detected in the glomeruli of these patients, suggesting that hepatitis $B$ virus may be implicated in the pathogenesis of the disease. ${ }^{34}$ In most cases, however, hepatitis B virus infection remains asymptomatic until the development of membranous glomerulonephritis, although at this time a variety of associated liver disorders has been reported. ${ }^{23}$ Therefore no clear cut relation has emerged between the natural history of the infection and of the associated liver disease and the development of membranous glomerulonephritis. We described the clinical and virological features and the unusual course of chronic active hepatitis type B in a child who developed membranous glomerulonephritis two years after the clinical onset of liver disease.

\section{Case report}

This boy, the first child of a 27 year old mother, was born after an uncomplicated pregnancy and delivery. He was well until the age of 18 months (July 1979) when he presented at Padova Hospital with abdominal pain that subsided spontaneously. On that occasion routine tests showed increased transaminase concentrations (Figure), and hepatitis B surface and $e$ antigen positivity by radioimmunoassay. Both urine analysis and blood urea nitrogen were normal. No risk factors for hepatitis B virus infection emerged from the clinical history of the patient and both parents were hepatitis B surface antigen negative. After discharge the patient remained asymptomatic. He was next seen in March 1980 when his mother developed acute hepatitis type B. At this time the child was an asymptomatic, well developed, and well nourished child with mild hepatosplenomegaly. Transaminase activities were 
considerably raised (Figure), while bilirubin, albumin, gammaglobulins, prothrombin time, $\mathrm{C} 3$ and $\mathrm{C} 4$ values were normal. Rheumatoid factors and antinuclear antibodies were negative. The patient was hepatitis B surface and e antigen positive, according to radioimmunoassay, and DNA polymerase positive (by the method of Kaplan et al).$^{5}$ There were no clinical or biochemical signs of renal disease. Liver biopsy, performed by the Menghini technique, showed features of chronic hepatitis with moderate signs of activity. Hepatitis B core antigen was found in the liver by direct immunofluorescence. ${ }^{6}$ One month later (April 1980), spontaneous seroconversion to hepatitis B e antibody occurred, although DNA polymerase was still positive in serum, and transaminases remained abnormal.

The patient remained asymptomatic until December 1981, when he developed bouts of abdominal pain, anorexia, vomiting, peripheral oedema, and ascites, and was admitted to hospital. On examination he was found to have severe, generalised oedema and slight hepatosplenomegaly. Laboratory data were as follows: total serum protein $4.4 \mathrm{~g} / 100$ $\mathrm{ml}$; cholesterol $6.7 \mathrm{mmol} / \mathrm{l}(260 \mathrm{mg} / 100 \mathrm{ml})$; blood urea nitrogen $2.5 \mathrm{mmol} / \mathrm{l}(7 \mathrm{mg} / 100 \mathrm{ml})$; and creatinine $35.2 \mu \mathrm{mol} / \mathrm{l}(0.4 \mathrm{mg} / 100 \mathrm{ml})$. Rheumatoid factors and antinuclear antibody were negative. The complement profile showed: C3 $86 \mathrm{mg} / 100 \mathrm{ml}$ (normal 80 to $150 \mathrm{mg} / 100 \mathrm{ml}$ ) and C4 $15 \mathrm{mg} / 100 \mathrm{ml}$ (normal 15 to $45 \mathrm{mg} / 100 \mathrm{ml}$ ). Proteinuria ranged from 5 to $16 \mathrm{~g} / 24$ hours and was highly selective. The urinary sediment showed 5 to 10 erythrocytes/high power field and some granular hyaline casts. Both hepatitis $\mathrm{B}$ e antigen and antibody were simultaneously detected in serum. Renal biopsy was consistent with membranous glomerulonephritis. Direct

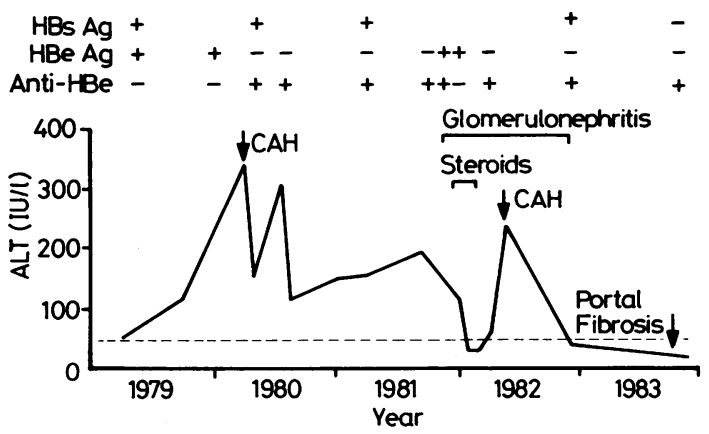

Figure Behaviour of alanine aminotransferase $(A L T)$ and of hepatitis $B$ virus $(\mathrm{HBV})$ markers in serum during the observation period.

Dotted line indicates the upper normal value of ALT;CAH=chronic active hepatitis. $\mathrm{HBsAg}=$ hepatitis $\mathrm{B}$ surface antigen; $\mathrm{HBeAg}=$ hepatitis $\mathrm{B}$ e antigen; Anti-HBe $=$ hepatitis $B$ e antibody immunofluorescence on frozen tissue sections using commercial antisera (Behringwerke) showed granular deposits of $\mathrm{IgG}, \mathrm{IgM}, \mathrm{C} 3$, and $\mathrm{Clq}$ in the capillary loops. Staining for hepatitis B surface antigen by indirect technique using a FITCconjugated goat antiserum to monospecific rabbit hepatitis B surface antibody (Behringwerke) was negative. Staining for hepatitis $B$ e antigen could not be performed.

The patient was given immunosuppressive treatment at a dose of $2 \mathrm{mg} / \mathrm{kg} /$ day. The transaminases activities and the hepatitis $\mathrm{B}$ e antigen/antibody system during the observation period are shown in the Figure.

Two months later (February 1982) peripheral oedema had resolved and steroid treatment was stopped. In April 1982, when proteinuria had reduced to 2 to $3 \mathrm{~g} /$ day, a percutaneous liver biopsy was carried out and was again consistent with chronic hepatitis of moderate activity. Hepatitis B core antigen was detectable by immunofluorescence in few hepatocyte nuclei. The patient's ambulatory course, over the next four months was one of gradual improvement of renal function and a return of transaminase activities to normal. DNA polymerase became negative in serum. By November 1982 proteinuria had resolved and transaminases were normal. Nine months later the patient no longer had hepatitis B surface antigen in serum and became hepatitis B surface antibody positive. A liver biopsy performed in November 1983 showed features of portal fibrosis and no hepatitis B virus markers could be found by immunofluorescence.

\section{Discussion}

Membranous glomerulonephritis occuring in chronic hepatitis B surface antigen carriers is thought to be mediated by immune complexes involving hepatitis B virus antigens. ${ }^{34} 7 \mathrm{As}$ membranous glomerulonephritis, however, is certainly a rare clinical finding during chronic hepatitis $B$ virus infection, nephritogenic immune complexes are probably produced only in patients with a peculiar type of immune response to the virus. Indeed our patient had some unique clinical and immunological features during the natural history of his liver disease, before the development of glomerulonephritis. He was, in fact, the only case out of 13 untreated children with chronic hepatitis $B$ e antigen positive hepatitis included in a previous study,${ }^{8}$ who did not show biochemical and histological remission of liver disease after hepatitis B e antibody seroconversion, and who showed spontaneous fluctuations of circulating hepatitis B e antigen/antibody. Urine analysis remained normal for a long time in spite of 
active liver disease and continuing virus replication, and glomerulonephritis occurred only when both hepatitis B e antigen and antibody were simultaneously detectable in serum, thus suggesting that this antigen-antibody complex, with a molecular ratio near to equilibrium, might by of pathogenetic importance. In fact the complex has a molecular size thought to be capable of inducing glomerular disease and recently Takekoshi $e t a l^{4}$ and Ito et $a l^{7}$ found hepatitis B e antigen without surface antigen, in the glomerular deposits of some children with membranous glomerulonephritis. Moreover an association was found between the hepatitis B e antigen/antibody status and outcome of glomerulonephritis. Resolution of the disease was often associated with hepatitis B e antibody seroconversion. Even in our patient this seroconversion was followed by a rapid return to normal of the urine analysis but only when it was associated with the end of hepatitis $B$ virus replication and subsequent remission of liver disease. The favourable outcome of both hepatic and renal disease after the end of virus replication provides further support to the concept that both diseases, although occuring at different times and with different pathogenetic mechanisms, are due to the same aetiological agent. In our experience, more that $90 \%$ of children with chronic hepatitis type B remain chronic surface antigen carriers after hepatitis B e antibody seroconversion (unpublished observations). Our patient was one of the few in whom hepatitis B surface antigen was no longer found in serum some months after seroconversion. Why he finally developed an adequate immune response to hepatitis $B$ virus remains unclear.

Since the end of hepatitis B virus replication seems to be a crucial event in the remission of both hepatic and extrahepatic disorders associated with the chronic infection, immunosuppressive treatment that potentiates virus replication would not find a rationale in the treatment of hepatitis $B$ virus associated membranous glomerulonephritis. In our patient, however, short term immunosuppressive treatment, given at the onset of the nephrotic syndrome, did not seem to interfere with the favourable outcome of the infection and related disorders.

\section{References}

${ }^{1}$ Brzosko WJ, Krawczynski K, Nazarewicz T, Morzycka M, Novoslawski A. Glomerulonephritis associated with hepatitis B surface antigen immune complexes in children. Lancet 1974;ii: 477-82.

${ }^{2}$ Wiggelinkhuizen J, Sinclair-Smith C, Stannard LM, Smuts H. Hepatitis B virus associated membranous glomerulonephritis. Arch Dis Child 1983;58:488-96.

${ }^{3}$ Slusarczyk J, Michlak T, Nazarewicz-de Mezer T, Krawczynsky K, Novoslawski A. Membranous glomerulopathy associated with hepatitis B core antigen immune complexes in children. Am J Pathol 1980;98:29-39.

4 Takekoshi Y, Tanaka M, Miyakawa Y, Yoshizawa H, Takahashi K. Mayumi M. Free 'small' and IgG-associated 'large' hepatitis $\mathrm{B}$ e antigen in the serum and glomerular capillary walls of 2 patients with membranous glomerulonephritis. $N$ Engl $J$ Med 1979;300:814-9.

5 Kaplan PM, Greenman RL, Gerin JL, Purcell RH, Robinson WS. DNA polymerase associated with human hepatitis B antigen. J Virol 1973;12:995-1005.

6 Bortolotti F, Alberti A, Cadrobbi P, Rugge M, Armigliato M, Realdi G. Prognostic value of hepatitis B core antigen ( $\mathrm{HBcAg}$ ) expression in the liver of children with chronic hepatitis type $B$. Liver 1985;5:40-7.

${ }^{7}$ Ito H, Hattori S, Matusda I, et al. Hepatitis B e antigenmedicated membranous glomerulonephritis. Lab lnvest 1981; 44:214-20

${ }^{8}$ Bortolotti F, Cadrobbi P. Crivellaro C, et al. Changes in hepatitis $\mathrm{Be}$ antigen/antibody system in children with chronic hepatitis B virus infection. J Pediatr 1983;103:718-22.

Correspondence to: Dr Flavia Bortolotti, Istituto di Medicina Clinica, Clinica Medica 2a, Via Giustiniani 2, 35100 Padova, Italy.

Received 5 February 1985

\section{Recurrent croup}

\section{W HIDE AND B M GUYER}

Paediatric Department, St Mary's Hospital, Isle of Wight

SUMmARY Thirty one of 486 children followed from birth had recurrent croup in the first four years of life. Twenty one were boys, and 10 girls. Recurrent croup occurred significantly more often in families with a positive history of allergy but was not significantly associated with the initial feeding method.
Recurrent croup was an unexpectedly common clinical occurrence identified in $6 . \overline{4 \%}$ of the infant population of the Isle of Wight born dering a 12 month period and followed for the first four years of life. Detailed results of the first two years of the Isle of Wight infant feeding survey have been published. ${ }^{1-3}$

We wish to draw particular attention to recurrent 